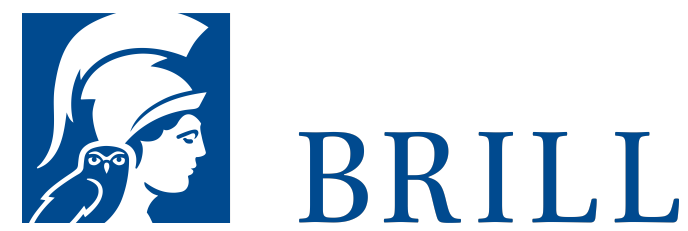

\title{
Kants Gesamtwerk in neuer Perspektive
}

\author{
Author: Maja Schepelmann
}

Anders als in historisierenden Deutungen wird in dieser neuen Darstellung des Kantischen Gesamtwerks dem Autor in allen literarischen und philosophischen Belangen die volle Souveränität über die Gestaltung des Werkganzen zugesprochen. In dieser neuen Perspektive stellt sich sein Gesamtwerk als eine einzige konsistente Argumentation dar, die ihre Untersuchungshinsichten auf unterschiedliche Schriften verteilt, unter Verwendung satirischer und ironischer Gestaltungsmittel bestimmte Positionen der Tradition teils scharf kommentiert, auf den hintersinnigen Spott der frühen Schriften diejenigen Schriften folgen lässt, in denen Grundlagen und Prinzipien des philosophischen Systems sowie deren Rechtfertigung fundiert werden, und die schließlich von dort den Überstieg zur Anwendung in Wissenschaft und Gesellschaft in Angriff nimmt. Dabei wird stets die methodologische Idee verfolgt, dass, auch mittels absichtlich inszenierter Irritationen, der LeserIn immer wieder auf sich selbst gestellt sein sollen, um das eigene Denken einzuüben und um es als solches überhaupt zu bemerken. So muss also Kants rhetorische und literarische Konzeption der erste Schlüssel zu seinem Verständnis sein.

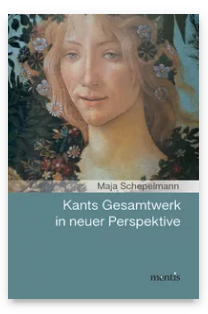

Pages: 520

Seiten

Language:

German

Subjects:

General,

Philosophy

Publisher: Brill | mentis

E-Book (PDF)

Released online: $27 \mathrm{Jul} 2017$

ISBN: 978-3-

95743-822-5

List price

Hardback

Publication date: 25 Jul 2017

ISBN: 978-395743-09o-8

List price 
For more information see brill.com

Order information: Order online at brill.com +44330 333 0049 | customerservices@brill.com Submission information: brill.com/authors

Titles published by Brill | Fink, Brill | mentis or Brill | Schöningh: +49(o)715413279216| brill@brocom.de 